\title{
PENGARUH MODEL PEMBELAJARAN KOOPERATIF TIPE INKUIRI TERHADAP HASIL BELAJAR SISWA KELAS IV SD
}

\author{
Santa Nadia Br Purba ${ }^{1}$, Reflina Sinaga ${ }^{2}$, Juliana $^{3}$, Patri Janson Silaban ${ }^{4}$ \\ 1,2,3,4 Universitas Katolik Santo Thomas, Medan, Indonesia \\ Inadiasanta72@gmail.com, ${ }^{2}$ reflina_sinaga@ust.ac.id, ${ }^{3}$ anna.jait@gmail.com, ${ }^{4}$ patri.jason.silaban@gmail.com
}

\begin{abstract}
ABSTRAK
Penelitian ini bertujuan untuk mengetahui pengaruh Model Pembelajaran Kooperatif Tipe Inkuiri Terhadap Hasil Belajar Siswa Pada Tema Indahnya Keragaman Di Negeriku Kelas IV SDN 060938 Medan Johor Tahun Pembelajaran 2020/2021. Populasi penelitian ini adalah seluruh siswa kelas IV SDN 060938 Medan Johor berjumlah 30 siswa. Pengambilan sampel menggunakan boring sampling dan sampel sebanyak 30 siswa. Metode yang digunakan dalam penelitian ini adalah metode deskriptif analitik. Hasil penelitian ini menunjukkan bahwa hasil belajar siswa menggunakan model pembelajaran Kooperatif Tipe Inkuiri termasuk ke kategori baik sekali dengan rata-rata 82.96. Pengujian normalitas diperoleh nilai signifikansi hasil belajar adalah $\mathrm{L}_{\text {hitung }}>\mathrm{L}_{\text {tabel }}$ yaitu $0.178>0.05$. Berdasarkan perhitungan tersebut dapat diketahui bahwa nilai signifikansi dari hasil belajar berdistribusi normal. Pada pengujian korelas, nilai koefisien sebesar 0.621 artinya $r_{\text {hitung }}>r_{\text {tabel }}$ yaitu $0.621>0.361$. Hasil pengujian uji-t dimana $t_{\text {hitung }}>t_{\text {tabel }}$ yaitu 4.195 $>1.697$ sehingga $\mathrm{H}_{\mathrm{a}}$ diterima. Hal ini menunjukkan adanya pengaruh positif dan signifikan dari pengaruh Model Pembelajaran Kooperatif Tipe Inkuiri Terhadap Hasil Belajar Siswa Pada Tema Indahnya Keragaman Di Negeriku Kelas IV SDN 060938 Medan Johor Tahun Pembelajaran $2020 / 2021$.
\end{abstract}

Kata Kunci: hasil belajar, model pembelajaran kooperatife tipe inkuiri

\section{THE EFFECT OF COOPERATIVE TYPE INQUIRY LEARNING MODEL ON STUDENTS' LEARNING OUTCOMES AT GRADE IV ELEMENTARY SCHOOLS}

\section{ABSTRACT}

This study aimed to determine the effect of using the Cooperative Type Inquiry learning model on students' learning outcomes on the theme of "Indahnya Keberagaman di Negeriku" at grade IV SDN 060938 Medan Johor Academic Year 2020/2021. The population in this study were all students of grade IV SDN 060938 Medan Johor Academic Year 2020/2021. The samples were chosen by boring sampling with 30 students. The method in this study was descriptive-analytical. The results of this study indicated that the students' learning outcomes after the implementation of Cooperative Type Inquiry models were categorized as excellent with an average of 82.96. The normality test obtained the significance score of learning outcomes was $L_{\text {count }}>$ $L_{\text {table }}$ or $0.178>0.05$. Based on the calculation, it was seen that the significance value of learning outcomes was normally distributed. The correlation testing obtained the coefficient score for 0.621 in which $r_{\text {count }} \geq r_{\text {table }}$ or $0.621>0.361$. The result of the t-test was $4.195>1.697$ meaning that Ha was accepted. It indicated that there was a positive influence and significant effect of using the Cooperative Type Inquiry learning model on students' learning outcomes on the theme of "Indahnya Keberagaman di Negeriku" at grade IV SDN 060938 Medan Johor Academic Year 2020/2021. Keywords: learning outcomes, cooperative type inquiry

\begin{tabular}{|c|c|c|}
\hline Submitted & Accepted & Published \\
\hline 22 Juli 2021 & 19 Oktober 2021 & 24 November 2021 \\
\hline
\end{tabular}

\begin{tabular}{|l|c|r|}
\hline Citation & $:$ & $\begin{array}{r}\text { Br Purba, S.N., Sinaga, R., Juliana, J., \& Silaban, P.J. (2021). Pengaruh Model Pembelajaran Kooperatif Tipe Inkuiri } \\
\text { Terhadap Hasil Belajar Siswa Kelas IV SD. Jurnal PAJAR (Pendidikan dan Pengajaran), 5(6), 1614-1625. DOI : } \\
\text { http://dx.doi.org/10.33578/pjr.v5i6.8479. }\end{array}$ \\
\hline
\end{tabular}

\section{PENDAHULUAN}

Pendidikan sangat penting dan tidak bisa diabaikan, terutama didalam persaingan yang semakin meningkat. Pendidikan dilaksanakan secara sistematis dan terencana agar tujuan dari pendidikan tersebut dapat tercapai sesuai yang diharapkan melalui kegiatan pembelajaran efektif dan efesien. Kegiatan pembelajaran terdiri atas perencanaan, pelaksanaan penilaian. Perencanaan mencakup pembuatan silabus dan rencana pelaksanan pembelajaran (RPP). Melalui perencanaan diharapkan kegiatan pembelajaran menjadi terarah sesuai dengan tujuan yang ditentukan. Pelaksanaan pembelajaran meliputi kegiatan penyampaian materi dengan menggunakan stategi atau model tertentu supaya pembelajaran dapat berjalan efektif. Semakin tinggi pendidikan yang akan dicapai seseorang maka akan semakin baik kehidupannya.

Menurut Sinaga (2021:162) menyatakan "Pendidikan adalah suatu usaha yang dilakukan 
seseorang untuk meningkatkan potensi dirinya. Pendidikan mempunyai peranan yang sangat menentukan bagi perkembangan diri individu, terutama bagi bangsa dan Negara. Perkembangan zaman yang semakin modern terutama pada era globalisasi seperti sekarang ini menuntut adanya sumber daya manusia yang unggul yang selalu berubah-ubah". Pendidikan secara umum adalah suatu proses pengajaran terhadap pengetahuan, keterampilan, atau kebiasaan bagi peserta didik agar dapat mengetahui dan mengevaluasi menerapkan ilmu yang didapatkan dari pelajaran di kelas maupun pembelajaran dari pengalaman didalam kehidupan sehari-hari. Dalam dunia pendidikan harus ada proses belajar mengajar dilakukan supaya adanya interaksi guru dengan siswa. Guru dalam pandangan di masyarakat adalah seorang yang melakukan pendidikan di tempat tertentu, tidak mesti dilembaga formal, tetapi juga dilingkungan masyarakat maupum di dalam rumah. Guru menduduki kedudukan yang terhormat dalam pandangan masyarakat, dipandang dari kewibawaan guru sehingga masyarakan tidak meragukan sosok seorang guru. Dalam masyarakat meyakini bahwa gurulah yang bisa mendidik anak-anak mereka menjadi orang yang berkepribadianyang baik. Dengan demikian disimpulkan bahwa guru adalah orang yang mampu membimbing dan membina karakter anak didik dengan baik, antara di lingkungan sekolah dan diluar lingkungan sekolah. Guru merupakan tokoh utama dan menjadi contoh yang teladan bagi anak didiknya. Oleh karena itu guru harus memiliki pengetahuan dan keterampilan untuk mengenaik karakter dan memiliki karakter yang baik dalam dirinya sendiri, untuk mendapat hasil yang baik terhadap anak didik. Tugas seorang guru bukan hanya sebagai mentransfer ilmu, tetapi guru mampu menjadi motivator yang baik dan bisa menumbuhkan semangat baru dan minat siswa untuk mendapat hasil belajar yang baik. Guru mempunyai tujuan agar peserta didik berhasil dalam setiap pembelajaran. Tujuan pembelajaran dapat dicapai dengan melibatkan peran guru sebagai fasilitator yang diharapkan memiliki cara atau model mengajar yang baik dan mampu memilih model pembelajaran yang tepat dan sesuai dengan konsep pembelajaran yang akan disampaikan. Tujuan pendidikan tidak bisa lepas dari kurikulum sekolah.

Kurikulum yang diterapkan di Indonesia adalah kurikulum 2013 (K-13) yang sejalan dengan peraturan yang sudah ditetapkan. Kurikulum 2013 merupakan kurikulum yang menyempurnakan pola pembelajaran yang perpusat kepada guru menjadi pola pembelajaran yang berpusat kepada siswa. Dalam hal ini guru harus mampu menjadi fasilitator yang baik, mampu membangun potensi minat belajar dan keaktifan siswa. Salah satu model pembelajaran yang mampu mengembangkan peran guru sebagai motivator dan fasilitator yang baik untuk membangun minat belajar siswa yaitu Kooperatif Tipe Inkuiri.

Kooperatif Tipe Inkuiri adalah model yang merencanakan siswa dalam melakukan eksperimen sendiri secara luas supaya akan terjadi, memberikan pertanyaan, siswa berkeinginan mencari jawaban dengan sendiri. Dalam model ini menekankan siswa berfikir secara kritis dan analitis karena setiap siswa dituntut mampu memecahkan suatu masalah atau penelitian. Pemilihan model yang tepat akan dapat membantu guru untuk meningkatkan hasil pembelajaran dan menciptakan suasana kelas yang aktif.

Tematik merupakan pembelajaran yang menggunakan tema dalam mengaitkan beberapa mata pembelajaran sehingga dapat memberikan pengalaman bermakna kepada siswa. Tema dikembangkan dari luar mata pelajaran tetapi topik yang dibahas sejalan dengan standar isi dari setiap mata pelajaran. Dalam hal ini model pembelajaran Kooperatif Tipe Inkuiri sesuai dengan pembelajaran tematik.

Berdasarkan observasi awal di kelas IV SD Negeri 060938 Medan Johor dilakukan peneliti ada bebrapa hal faktor dari luar yang mempengaruhi hasil belajar anak didik. Faktorfaktor tersebut antara lain sikap guru yang tidak menentu, pengelolaan kelas, penggunaan media pembelajaran, pihak orang tua siswa. Sikap guru yang tidak menentu selama proses pembelajaran mempengaruhi hasil belajar siswa. Terkadang juga masih ada sikap guru otoriter, sikap guru tertutup kepada siswa yang membuat siswa juga tertutup terhadap guru. Jika guru belum bisa 
mengoptimalkan sikap kepemimpinannya yang digunakan dalam proses pembelajaran maka siswa tidak mendapatkan hasil belajar yang baik dan suasana di kelas tidak hidup dan membosankan. Untuk mengatasi itu perlu dikembangkan sikap yang demokratis dan terbuka terhadap siswa supaya siswa juga dapat terbuka kepada gurunya.

Pengelolaan kelas juga dapat mempengaruhi hasil belajar siswa. Jika guru berhasil dalam mengelola kelas maka akan tercipta suasana belajar yang kondusif dan terjadinya hubungan baik antara guru dengan siswa. Model pembelajaran Kooperatif Tipe Inkuiri sangat mepengaruhi tercapainya hasil belajar siswa. Salah satunya model pembelajaran Kooperatif Tipe Inkuiri ini merupakan dimana siswa dapat menemukan suatu masalah dan dapat menegtahui bagaimana cara untuk memecahkan masalah dalam suatu penelitian ataupun kegiatan pembelajaran yang menekankan berfikir kritis dan analitis pada siswa. Dengan model pembelajaran yang tepat digunakan dalam sistem pembelajaran akan mengobtimalkan dan memaksimalkan keberhasilan belajar di kelas serta menumbuhkan minat belajar siswa untuk mendapatkan hasil belajar yang baik.

Tabel 1. Nilai Ulangan Harian

\begin{tabular}{ccccc}
\hline KKM & $\begin{array}{c}\text { Muatan } \\
\text { Pelajaran }\end{array}$ & Jumlah Siswa & $\begin{array}{c}\text { Persentase } \\
(\mathbf{\%})\end{array}$ & Keterangan \\
\hline$\geq 70$ & B.Indonesia & 12 & $40 \%$ & Tuntas \\
& & 18 & $60 \%$ & Tidak Tuntas \\
$\geq 70$ & IPA & 11 & $36.67 \%$ & Tuntas \\
& & 19 & $63.33 \%$ & Tidak Tuntas \\
\hline
\end{tabular}

Berdasarkan tabel tersebut dari 30 siswa kelas IV SD Negeri 060938 Medan Johor, siswa yang tuntas belajarnya mencapai KKM sebanyak 12 siswa (40\%) yang tuntas dan yang 18 siswa $(60 \%)$ yang belum tuntas dalam muatan B.Indonesia dan dalam muatan IPA 11 siswa (36.67\%) dan yang belum tuntas mencapai KKM sebanyak 19 siswa (63.33\%). Dari jumlah siwa kelas IV masih banyak yang belum mencapai hasil yang maksimal dalam pelajaran tematik, permasalahan tersebut menunjukkan bahwa adanya siswa yang kurang terlibat dalam proses pembelajaran disebabkan karena guru mengajar hanya menggunakan metode ceramah sehingga siswa bosan dan malas untuk mengikuti kegiatan pembelajaran.

Meningkatkan mutu pendidikan adalah tanggung jawab semua pihak terutama guru sangat berperan penting di dalam proses pembelajaran. Namun pada kenyataannya guru masih jauh dari yang diharapkan dalam penggunaan model dan media dalam proses pembelajaran sehingga menjadi masalah serius, sehingga kualitas dalam pembelajaran masih jauh dari yang diharapkan dalam pelakaran tematik. Masih banyak guru menggunakan model konvensional dan penugasan, sehingga hasil belajar siswa masih rendah. Para guru belum sepenuhnya melaksanakan pembelajaran secara aktif dan kreatif dalam melibatkan siswa serta belum melibatkan berbagai pendekatan/strategi pembelajaran yang bervariasi berdasarkan karakteristik mata pelajaran. Dalam proses belajar mengajar, guru hanya terpaku pada buku teks sebagai satu-satunya sumber belajar mengajar.

\section{KAJIAN TEORETIS}

\section{Model Pembelajaran Kooperatif Tipe Inkuiri}

Pembelajaran inkuiri suatu strategi yang membutuhkan siswa menemukan sesuatu dan mengetahui bagaimana cara memecahkan masalah dalam suatu penelitian ilmiah. Hal ini tak berarti bahwa guru menghentikan memberikan suatu bimbingan setelah problem disajikan kepada pelajar. Akan tetapi, bimbingan yang diberikan tidak hanya dikurangi direktifnya, tetapi diberi responsibilitas yang lebih besar untuk belajar sendiri. Dalam hal ini, perlu dibutuhkan kesiapan dari peserta didik.

Menurut Shohimin (2016:85) menyatakan bahwa pembelajaran inkuiri adalah kegiatan pembelajaran di mana siswa didorong untuk belajar melalui keterlinatan aktif mereka sendiri dengan konsep-konsep dan prinsip-prinsip, dan 
guru mendorong siswa memiliki pengalaman dan melakukan percobaan yang memungkinkan siswa menemukan prinsip-prinsip untuk diri mereka sendiri.

Menurut Kurniasih \& Sani (2016:113) model pembelajaran inkuiri merupakan pembelajaran dengan seni merekayasa situasisituasi yang sedemikian rupa sehingga siswa bias berperan sebagai ilmuan. Siswa diajak untuk bisa memiliki inisiatif untuk mengamati dan menanyakan gejala alam, mengajukan penjelasanpenjelasan tentang apa yang mereka lihat, merancang dan melakukan pengujian untuk menunjang atau menentang teori-teori mereka, menganalisis data, menarik kesimpulan dari data eksperimen, merancang dan membangun model.

Menurut Fathurrohman (2015:105) Model Pembelajaran Inkuiri adalah seni tentang mengajukan dan menjawab pertanyaan-pertanyaan yang menghendaki pengamatan dan pengukuran, pengajuan hipotesis, dan penafsiran, pembangunan, pemgujian model melalui eksperimen, refleksi, dan pengakuan atas kekuatan-kekuatan dan kelemahan-kelemahan dari metode pendidikan yang digunakan. Selama inkuiri, guru dapat mengajukan suatu pertanyaan atau mendorong sisiwa mengajukan pertanyaanpertanyaan mereka sendiri, yang dapat bersifat oprn-ended, memberi peluang bagi siswa untuk mengarahkan penyelidikan mereka sendiri, dan menemukan jawaban-jawaban yang mungkin dari mereka sendiri, dan mengantar pada lebih banyak pertanyaan lain.

Berdasarkan pendapat para ahli yang dikemukakan diatas, dapat disimpulkan bahwa model pembelajaran inkuiri adalah rangkaian kegiatan pembelajaran yang menekanakan pada keaktifan siswa untuk memiliki pengalaman belajar dalam menemukan konsep-konsep materi berdasarkan masalah yang diajukan.

\section{METODE PENELITIAN}

Pendekatan penelitian ini adalah penelitian kuantitatif. Menurut (Azwar, 2016) penelitian kuantitatif menekankan analisisnya pada data-data numerical (angka) yang diolah dengan metode statistika. Pada dasarnya, pendekatan kuantitatif dilakukan pada penelitian inferensial (dalam rangka pengujian hipotesis) dan menyadarkan kesimpulan hasilnya pada suatu probilitas kesalahan penolakan hipotesis nihil. Dengan metode kuantitatif akan diperoleh signifikansi perbedaan kelompok atau signifikansi hubungan antar variaber yang diteliti. Pada umumnya, penelitian kuantitatif merupakan penelitian sampel besar.

Menurut Sugiyono (2010:2) metode penelitian pada dasarnya merupakan cara ilmiah untuk mendapatkan data dengan tujuan dan kegunaan tertentu. Berdasarkan hal tersebut terdapat empat kata kunci yang perlu diperhatikan yaitu, cara ilmiah, data, tujuan, dan kegunaan tertentu yang didasarkan pada ciri-ciri keilmuan yaitu, rasional, empiris, dan sistematis. Maka metode penelitian yang digunakan dalam penelitian ini adalah metode deskriptif. Metode deskriptif merupakan metode penelitian yang bermaksud menjelaskan kedudukan variabel yang diteliti serta pengaruh antara suatu variabel dengan variabel yang lain. Penelitian ini akan dilaksanakan pada siswa kelas IV SD Negeri 060938 Medan Johor Tahun pembelajaran 2020/2021. Tempat penelitian ini beralamat Jln. Luku 1 Kwala Bekala Medan Johor. Populasi penelitian menjadi penting karena sebagai objek/subjek dari suatu penelitian adalah bagian dari populasi. Populasi diartikan sebagai keseluruhan subjek penelitian. Menurut Sugiyono (2010:80) menyatakan "Populasi adalah wilayah generalisasi yang terdiri atas: obyek/subyek yang mempunyai kualitas dan karakteristik tertentu yang ditetapkan oleh peneliti untuk dipelajari dan kemudian ditarik kesimpulannya". Berdasarkan pendapat tersebut dan sesuai dengan judul penelitian ini maka populasi dalam penelitian adalah seluruh siswa kela IV SD yang terdiri dari dua kelas yaotu IVA (30 siswa) sehingga jumlah seluruh siswa kelas IV SD berkisar 30 siswa di SD Negeri 060938 Medan Johor.

Menurut Sugiyono (2010:81) "Sampel adalah bagian dari jumlah dan karakteristik yang dimiliki oleh populasi tersebut". Sampel penelitian ini adalah kelas IV SD Negeri 060938 Medan Johor Tahun Pembelajaran 2020/2021 yang berjumlah 30 siswa. Pengambilan sampel pada penelitian ini dilakukan Boring Sampling (Sampling Jenuh). Sugiyono (2010:85) "Boring Sampling adalah teknik penentuan sampel bila 
smeua anggota populasi digunakan sebagai sampel. Hal ini sering dilakukan bila jumlah populasi relative kecil, kurang 30 orang, atau penelitian yang ingin membuat generalisasi dengan kesalahan yang sangat kecil. Istilah lain sampel jauh adalah sensus, dimana semua anggota populasi dijadikan sampel”.

\section{Teknik dan Alat Pengumpulan Data}

Teknik pengumpulan data adalah cara yang digunakan untuk mengumpulkan data. Menurut Manullang \& Pakpahan (2014:90). Teknik Pengumpulan data adalah merupakan cara untuk mengumpulkan data-data yang relevan bagi penelitian, karena tujuan utama dari penelitian adalah mendapatkan data. Tanpa mengetahui teknik pengumpulan data, maka peneliti tidak akan mendapatkan data yang memenuhi standar data yang ditatapkan. Pengumpulan data yang dilakukan dengan menggunakan dua teknik pengumpulan data yaitu tes dan non tes.

\section{Teknik Tes}

Menurut Darmadi (2014:137) menyatakan tes adalah prosedur sistematik diminta individual yang dites direpresentasikan dengan suatu set stimuli jawaban mereka yang dapat menunjukkan kedalam angka.

\section{Observasi}

Observasi merupakan teknik pengumpulan data dengan cara mengamati. Menurut Hadi (Sugiyono, 2010:145) observasi adalah suatu proses yang kompleks, suatu proses yang tersusun dari berbagai proses biologis dan psikologis. Dua diantara yang terpenting adalah proses-proses pengamatan dan ingatan.

\section{Dokumentasi}

Sebagian besar data yang tersimpan dalam bahan yang bentuk dokumentasi, Arikunto (2018:201) menyatakan bahwa dokumentasi yaitu mencari data mengenai hal-hal atau variabel yang berupa cacatan, transkip, buku, surat kabar, majalah, notulen rapat, agenda, foto, dan sebagainya.

\section{Uji Validitas Data dan Instrumen}

Instrument yang digunakan dalam penelitian ini berupa tes soal yang dibuat sendiri oleh peneliti. Menurut Sugiyono (2010:121) instrument penelitian yaitu penelitian yang berkenan dengan validitas dan reabilitas instrument dan kuantitas perkumpulan data berkenaan ketepatan cara-cara yang digunakan untuk mengumpulkan data. Maka dalam penelitian ini peneliti menggunakan tes sebagai instrument penelitian.

Dengan demikian penggunaan instrument yaitu untuk mencari informasi yang lengkap mengenai suatu masalah instrument yaitu untuk mencari informasi yang lengkap mengenai suatu masalah fenomena alam maupun social. Instrumen yang baik apabila memenuhi syarat sebagai instrument yang standar, instrument standar instrument itu valit atau tetap.

\section{Uji Validitas}

Uji validitas adalah pengujian suatu alat ukur yang digunakan untuk mengukur variabel yang ada. Menurut Arikunto (2018:211) menyatakan validitas adalah suatu ukuran yang menunjukkan tingkat-tingkat kevalidan atau kesahihan suatu instrument. Suatu instrument yang kurang valid berarti memiliki validitas rendah. Dalam penelitian, validitas tes ukur dengan korelasi prodact moment : cara digunakan untuk mengetahui tingkat validitas instrument pada penelitian ini adalah menggunakan rumus korelasi.

Menurut Arikunto (2018:213) sebagai berikut :

$r_{x y}=\frac{N \sum X Y-\left(\sum X\right)\left(\sum Y\right)}{\left.\sqrt{\left(N \sum X^{2}\right.}-\left(\sum X\right)^{2}\right)\left(N \sum Y^{2}-\left(\sum Y\right)^{2}\right\}}$

Keterangan :

rxy = koefisien korelasi antara $\mathrm{x}$ dan $\mathrm{y}$, yaitu bilangan yang menunjukkan besar kecilnya hubungan antara variabel $x$ dan variabel $y$

$\mathrm{N} \quad=$ banyaknya responden

$\sum X=$ jumlah seluruh skor $X$

$\sum Y=$ jumlah seluruh skor $Y$

$\sum X Y=$ jumlah hasil perkalian skor $\mathrm{X}$ dan $\mathrm{Y}$ 
Untuk menentukan instrument valid atau tidaknya diperlukan bantuan program SPSS Ver 22.0 adalah sebagai berikut :

a. Jika rhitung $\geq$ dengan taraf signifikan $0,5 \%$, maka instrument tersebut dikatakan valid.

b. Jika rhitung $\leq$ dengan taraf signifikan $0,5 \%$, maka instrument tersebut dikatakan tidak valid.

\section{Uji Reabilitas}

Reliabilitas ialah indeks yang menunjukkan sejauh mana alat ukur yang dipercaya. Menurut Arikunto (2018:221) bahwa sesuatu instrument cukup dapat dipercaya untuk digunakan sebagai alat pengumpulan data karena instrument sudah baik. Instrument yang baik tidak akan bersifat terdendius mengarahkan responden untuk memilih jawaban-jawaban tertentu. Pada penelitian ini menggunakan rumus Alpa dengan berbatukan SPSS ver 22.0. Rumus reabilitas menggunakan rumus Alpha sebagai berikut:

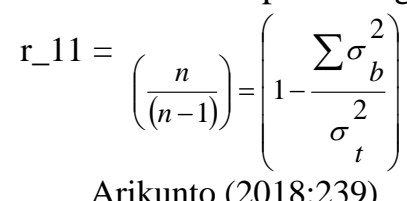

Keterangan:

r_11 = Reliabilitas angket yang dicari

$\sum \sigma_{b}^{2}=$ Jumlah varians skor tiap-tiap item

2

$\sigma_{t}^{2}$

$\sigma_{t}=$ Varians total

$\mathrm{n} \quad=$ Banyaknya butir pertanyaan

Interpretasi koefisien terhadap hasil perhitungan nilai koefisien korelasi $r_{-}$11mengacu pada pendapat Arikunto (2018:89) sebagai berikut

Tabel 2. Interpretasi Koefisien Realibilitas

\begin{tabular}{ccc}
\hline No & Angka Korelasi & Rentang kategori \\
\hline 1 & $0,000-0,199$ & Sangat rendah \\
2 & $0,200-0,399$ & Rendah \\
3 & $0,400-0,599$ & Sedang \\
4 & $0,600-0,799$ & Kuat \\
5 & $0,800-1,000$ & Sangat kuat \\
\hline
\end{tabular}

\section{Uji Normalitas}

Dalam statistika parametris memberikan syarat bahawa setiap variabel yang akan dianalisis harus berdistribusi normal maka sebelum pengujian hipotesis yang dillakukan terlebih dahulu pengujian normalitas data. Uji normalitas dilakukan pada kedua variabel yang akan diteliti yaitu variabel bebeas $(\mathrm{X})$ dan variabel terikat $(\mathrm{Y})$. Untuk mengetahui data berdistribusi normal atau tidak, peneliti menggunakan analisa KolmogrovSmirnov dengan bantuan SPSS Ver. 22.0 hasil perhitungan menunjukkan data berdistribusi nolmal jika nilai Asymp. Sign lebih besar dari 0.05 maka data dapat dikatakan tidak berditribusi normal. Nilai Asymp. Sign dilihat dari hasil pengujian pada perhitungan Kolmogrov Smirnov test.

\section{Teknik Pengolahan (Analisis Data)}

Analisis data dilakukan setelah data terkumpul. Proses analisis data merupakan usaha untuk memperoleh jawaban permasalahan penelitian. Penelitian ini akan mengelola dan menganalisis data dengan menggunakan Statistik Program for Socoal Science (SPSS) 22.0 dan teknik analisis data yang digunakan dalam penelitian ini adalahdengan cara analisis regresi linear berganda, uji hipotesis.

\section{Uji Korelasi}

Untuk menegtahui aadda tidaknya pengaruh antara variabel brbas (X) dengan variabel terikat (Y), dengan rumus korelasi Product Moment yaitu :

$$
\mathrm{R}_{\mathrm{XY}}=\frac{N \sum X Y-\left(\sum X\right)\left(\sum Y\right)}{\sqrt{\left(\left(N \sum X^{2}-\left(\sum X\right)^{2}\right)\left(N \sum Y^{2}-\left(\sum Y\right)^{2}\right\}\right.}}
$$

Arikunto (2018:213)

Keterangan:

$\mathrm{Rxy}=$ Koefisioner korelasi Product moment 
$\mathrm{N} \quad=$ Jumlah seluruh siswa

$\Sigma \mathrm{x}=$ Skor item

$\Sigma \mathrm{Y}=$ Skor total seluruh siswa

$\Sigma \mathrm{XY}=$ Jumlah hasil perkalian antara skor "X" dan skor "Y"

Dapat disimpulkan bahwa rhitung > rtabel maka terdapat pengaruh antara variabel bebas dengan variabel terikat. Sebaliknya jika rhitung < rtabel maka tidak terdapat pengaruh antara variabel bebas dengan variabel terikat.

\section{Uji Hipotesis}

Pada penelitian ini, uji $\mathrm{t}$ digunakan mengetahui sejauh mana variabel kompetensi guru mampu menjelaskan pengaruh terhadap variabel hasil belajat. Untuk mengetahui pangaruh setiap variabel penelitimenggunakan uji t. Uji statistik $t$ pada dasarnya menunjukkan seberapa jauh pengaruh suatu variabel bebas dalam menerangkan variasi variabel terikat. Dengan rumus uji signifikasi korelasi product moment. Dengan berbantukan program SPSSVer 222.0

Adapun rumusnya, Sugiyono (2010:184) sebagai berikut:

$$
\mathrm{t}=r \frac{\sqrt{n-2}}{\sqrt{1-r^{2}}}
$$

Sugiyono(2010:184)

Keterangan:

$\mathrm{r}=$ Koefisioner Korelasi

$\mathrm{n}=$ Sampel

Hipotesis diterima jika thitung > ttabel begitu juga sebaliknya jika thitung $<$ ttabel maka hipotesis ditolak, dengan taraf kesalahan 5\%..

\section{HASIL DAN PEMBAHASAN}

Penelitian ini dilaksanakan di kelas IV SD Negeri 060938 Medan Johor terletak di Jln. Luku I Kwala Bekala Medan Johor. Penelitian ini dilakukan untuk mengetahui apakah ada pengaruh model pembelajaran kooperatif tipe inkuiri terhadap hasil belajar siswa. Penelitian ini dilakukan dalam dua dengan pembagian kuesioner dan soal kepada siswa kelas IV.

Kegiatan yang dilakukan pertama kali yaitu peneliti datang ke sekolah untuk menyampaikan surat izin penelitian dan menjumpai kepala sekolah dan wali kelas IV untuk meminta izin melakukan penelitian dan pembagian kuesioner dan soal di kelas. Dalam pembagian kuesioner dan soal peneliti mengucapkan salam terlebih dahulu kepada siswa kelas IV dan memberikan arahan kepada siswa tentang pengisian kuesioner dan soal yang akan diberikan. Setelah kuesioner dan soal diisi dan dikembalikan kepada peneliti. Peneliti memberikan pesan kepada siswa agar tetap selalu semangat dalam belajar.

\section{Skor nilai Pre-test dan Post-test Kelas eksperimen}

Peneliti terlebih dahulu menggunakan tindakan awal atau Pre Test pada 30 siswa sebelum mulai pembelajaran untuk mengetahui kemampuan siswa. Hasil Pre Test yang telah dilaksanakan menunjukkan bahwa kemampuan hasil belajar siswa pada subtema Keragaman Suku Bangsa dan Agama di Negeriku masih rendah. Hal ini dapat dilihat dari nilai Pre Test dan Post-Tes siswa.

\section{Eksperimen}

Data Nilai Pre-test dan Post-test kelas

$$
\begin{aligned}
& \text { a. Rata-rata }\left(\text { mean) variabel } \mathrm{X}_{1}\right. \\
& \begin{aligned}
\mathrm{M}_{\mathrm{x}} & =\frac{\sum f x}{n}=\frac{2.489}{30}=82.96 \\
\text { b. Standar Deviasi Variabel } \mathrm{X}_{1} & \\
\mathrm{SD} & =\sqrt{\frac{\sum f x 2}{n}} \\
& =\sqrt{\frac{209.445}{30}} \\
& =\sqrt{6.981,5} \\
& =83.55
\end{aligned}
\end{aligned}
$$

Keterangan :

$\mathrm{SD}=$ Standar Deviasi

$\sum \mathrm{Fx}=$ Jumlah dari hasil penelitian antara midpoint dari masing-masing interval, dengan frekuensinya $\mathrm{N}=$ Jumlah Siswa

c. Standar Eror Variabel $\mathrm{X}_{1}$

$$
\begin{gathered}
\mathrm{SE}_{\mathrm{m}}=\frac{S D}{\sqrt{N-1}} \\
=\frac{83,55}{\sqrt{30-1}} \\
=\frac{83,55}{\sqrt{29}}
\end{gathered}
$$




$$
\begin{aligned}
& \quad \frac{83,55}{5,38} \\
& =15.52 \\
& \text { Keterangan : } \\
& \mathrm{SE}_{\mathrm{m}}=\text { Mean yang dicari }
\end{aligned}
$$

$\mathrm{SD}=$ Standar Deviasi
$\mathrm{N}=$ Jumlah Siswa
$1=$ Bilangan Konstan
Dapat dilihat dari perbadingan nilai

Dapat dilihat dari perbadingan nilai tersebut melalui diagram batang yang dimana nilai
post-test lebih tinggi dibandingkan dengan pre-tes.

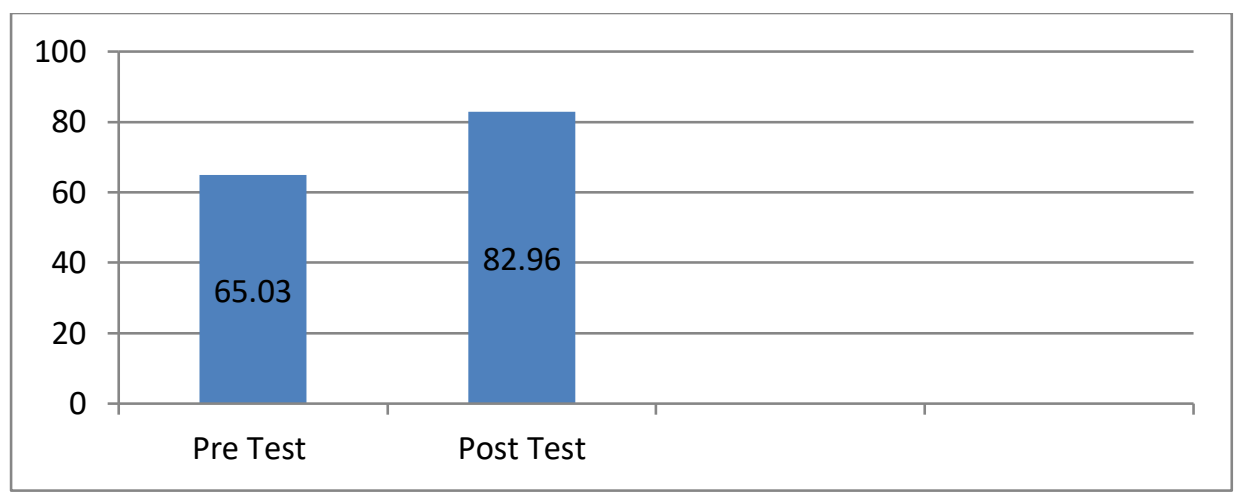

\section{Gambar 1 Diagram Nilai Rata-Rata Pre Test dan Post Test}

Berdasarkan diagram di atas, dapat dilihat bahwa nilai rata-rata post test hasil belajar lebih tinggi dari pada nilai rata-rata pre test sewaktu menjelaskan materi subtema Keragaman Suku Bangsa dan Agama di Negeriku.

\section{Uji Normalitas}

Uji Normalitas dilakukan untuk mengetahui apakah data dari Post Test hasil belajar kelas IV terdistribusi normal atau tidak. Data yang diuji adalah data Pre Test sebelum dilakukan tindakan atau tidak menggunakan perlakuan dengan data Post Test sesudah dilakukan tindakan dan perlakuan menggunakan model Kooperatif Tipe Inkuiri. Hasil perhitungan uji normalitas menggunakan program SPSS ver 22.

Tabel 4. Uji Normalitas

\begin{tabular}{llr}
\hline & One-Sample Kolmogorov-Smirnov Test & Unstandardized Residual \\
\hline $\mathrm{N}$ & & 30 \\
Normal Parameters & Mean & .0000000 \\
& Std. Deviation & 7.89112413 \\
Most Extreme Differences & Absolute & .134 \\
& Positive & .134 \\
& Negative & .108 \\
Test Statistic & & .134 \\
Asymp. Sig. (2-tailed) & & $.178^{\mathrm{c}}$ \\
\hline
\end{tabular}

Pengambilan keputusan dengan mengambil taraf signifikan 5\% adalah sebagai berikut:

1. Nilai Signifikansi (sig) $<0.05$ distribusi tidak normal
2. Nilai Signifikansi (sig) $>0.05$ distribusi normal Nilai taraf signifikansi yang digunakan oleh peneliti adalah taraf signifikansi $5 \%$ atau 0.05 . Berdasarkan uji liliefors (kolmogrov smirnov) didapatkan signifikansi sebesar 0.178 sehingga 
disimpulkan $0.178>0.05$ maka data kelas IV berdistribusi normal. Berdasarkan perhitungan tersebut dapat diketahui bahwa nilai signifikansi dari hasil belajar berdistribusi normal. Berikut gambar histogram dari normalitas:

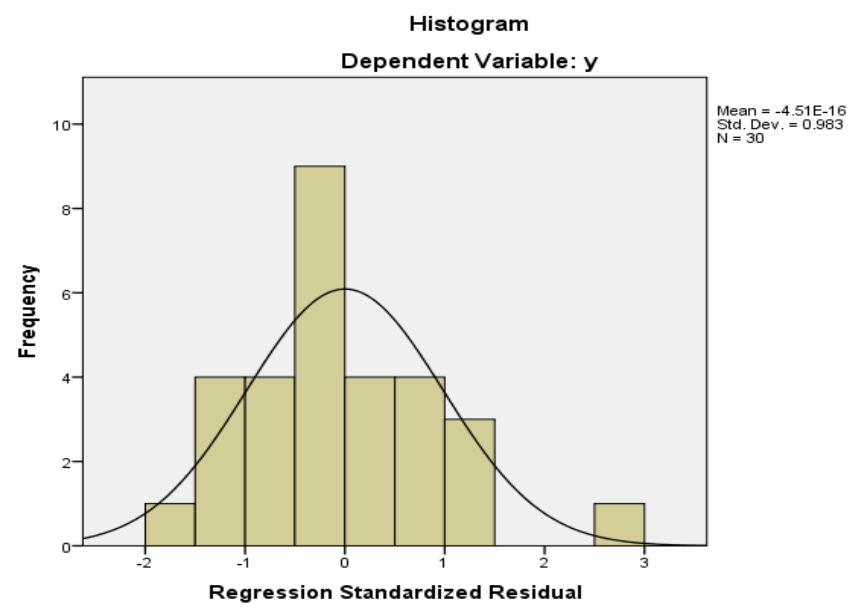

Gambar 2 Histogram Uji Normalitas

Berdasarkan grafik histogram di atas bahwa data yang terdapat pada garis melengkung yang membentuk lonceng terbalik dan titik tertinggi pada garis melengkung sejajar dengan 0 . Serta banyaknya angka di sebelah 0 sama banyaknya yaitu -2 dan 3 . Maka disimpulkan bahwa data tersebut seimbang.

\section{Uji Koefisien Korelasi}

Uji koefisien korelasi digunakan untuk mengetahui ada tidaknya pengaruh antara variabel bebas $(\mathrm{X})$ variabel $(\mathrm{Y})$, dan syarat untuk uji koefisien korelasi yaitu dengan melihat rhitung > rtabel dengan rumus korelasi product moment. Untuk melihat pengaruh dari kedua variabel dapat dilakukan dengan membandingkan antara rhitung dengan rtabel . Dari perhitungan di atas secara manual dapat dilihat nilai koefisien korelasi sebesar 0,621. Sedangkan uji koefisien korelasi berbantuan SPSS ver 22 pada tabel di bawah ini:

Tabel 5. Uji Koefisien Korelasi

\section{Correlations}

\begin{tabular}{rlrr}
\hline & & & $\mathrm{y}$ \\
& Pearson Correlation & 1 & $.621^{* *}$ \\
& Sig. (2-tailed) & & .000 \\
N & 30 & 30 \\
Pearson Correlation & $.621^{* *}$ & 1 \\
Sig. (2-tailed) & .000 & \\
N & 30 & 30 \\
\hline
\end{tabular}

Dari tabel di atas menujukkan bahwa nilai koefisien korelasi sebesar 0.621. Dari tabel di atas nilai koefisien korelasi sebesar 0.621 artinya rhitung $(0.621)>$ rtabel $(0.361)$. Maka terdapat pengaruh yang kuat antara model pembelajaran
Kooperatif Tipe Inkuiri terhadap hasil belajar siswa dan terdapat pengaruh antara model pembelajaran Kooperatif Tipe Inkuiri terhadap hasil belajar siswa kelas IV SDN 060938 Medan Johor sebesar $67 \%$ dan sebanyak 33\% dipengaruhi 
oleh faktor lain yang tidak dikaji dalam penelitian ini.

\section{Uji Hipotesis (Uji-t)}

Setelah data dinyatakan berdistribusi normal dan sampel berasal dari populasi yang sama atau homogen, maka selanjutnya dapat dilakukan pengujian hipotesis menggunakan "uji t". Statistik yang digunakan untuk menguji hipotesis penelitian adalah uji-t. Hipotesis yang diajukan adalah,
Ho: tidak ada pengaruh model pembelajaran Kooperatif Tipe Inkuiri terhadap hasil belajar siswa

Ha: ada pengaruh model pembelajaran Kooperatif Tipe Inkuiri terhadap hasil belajar siswa

Kriteria uji-t dapat dikatakan signifikan apabila diperoleh harga $\mathrm{p}<0,05$. Serta hipotesis diterima (Ha) jika thitung >ttabel dan di tolak (Ho) jika thitung < ttabel . Hasil perhitungan hipotesis uji t dapat dilihat pada tabel di bawah ini:

\begin{tabular}{|c|c|c|c|c|c|c|}
\hline \multicolumn{7}{|c|}{$\begin{array}{c}\text { Tabel 6. Uji-t } \\
\text { Coefficients }^{\mathbf{a}}\end{array}$} \\
\hline \multirow{4}{*}{$\begin{array}{l}\text { Model } \\
1\end{array}$} & \multirow{4}{*}{$\begin{array}{l}\text { (Constant) } \\
\mathrm{X}\end{array}$} & \multicolumn{2}{|c|}{ Unstandardized Coefficients } & \multicolumn{3}{|l|}{$\begin{array}{l}\text { Standardized } \\
\text { Coefficients }\end{array}$} \\
\hline & & B & Std. Error & Beta & $\mathrm{t}$ & Sig. \\
\hline & & 28.739 & 13.009 & & 2.209 & .036 \\
\hline & & .910 & .217 & .621 & 4.195 & .000 \\
\hline
\end{tabular}

Untuk mengetahui ada atau tidaknya pengaruh dapat dilihat hasil signifikan yang diperoleh $0.000<0.05$. Hasil perhitungan uji-t dari SPSS ver 22 sebesar 4.195. Untuk mendukung hasil uji-t dari SPSS ver 22, maka berikut hasil ujit secara manual. Dapat diketahui dari nilai $t_{\text {hitung }}>$ $\mathrm{t}_{\text {tabel }}$ yaitu $4.195>1.697$ yang artinya ada pengaruh model pembelajaran kooperatif Tipe Inkuiri terhadap hasil belajar siswa.

Hasil uji $t$ secara manual sebesar 4.195.Maka dapat diketahui dari nilai thitung > ttabel yaitu $4.195>1.697$ yang artinya ada pengaruh model pembelajaran Kooperatif Tipe Inkuiri terhadap hasil belajar siswa.

\section{Pembahasan}

Pada kelas IV dilakukan Pre Test dengan soal pilihan berganda, diperoleh hasil nilai terendah pre test 40 dan nilai tertinggi sebesar 76 . Nilai rata-rata Pre Test 55.6 berada dengan kategori kurang. Nilai rata-rata Post Test 82.96 berada dengan kategori baik sekali. Diperoleh nilai rata rata angket siswa yaitu sebesar 53.56. Nilai angket siswa terendah sebesar 52 dan nilai angket siswa tertinggi sebesar 70. Dengan persentase tertinggi sebesar $33.3 \%$ dan persentase terendah sebesar $10 \%$. Hasil normalitas dengan menggunakan taraf signifikan 5\% atau 0.05 dengan $\mathrm{r}_{\text {hitung }}<\mathrm{r}_{\text {tabel }}$ yaitu $0.178<0.05$. Dari hasil uji korelasi sebesar 0.621 artinya $r_{\text {hitung }}>r_{\text {tabel }}$ yaitu
$0.621>0.361$. Berdasarkan perhitungan hasil penelitian menunjukkan bahwa terdapat pengaruh model pembelajaran Kooperatif Tipe Inkuiri pada tema Indahnya Keragaman di Negeriku subtema Keragaman Suku Bangsa dan Agama di Negeriku di SD Negeri 060938 Medan Johor Tahun Pembelajaran 2020/2021 dengan $t_{\text {hitung }}>t_{\text {tabel }}$ dimana $4.195>1.697$ pada taraf signifikan $\alpha=$ 0,05 . Siswa dengan tema benda-benda di sekitar kita subtema benda zat tunggal dan campuran. Dengan demikian $\mathrm{H}_{\mathrm{a}}$ diterima dan $\mathrm{H}_{\mathrm{o}}$ ditolak.

\section{SIMPULAN DAN REKOMENDASI}

Pada kelas IV dilakukan Pre Test dengan soal pilihan berganda, diperoleh hasil nilai terendah pre test 40 dan nilai tertinggi sebesar 76 . Nilai rata-rata Pre Test 55.6 berada dengan kategori kurang. Kemudian di berikan perlakuan dengan menggunakan model pembelajaran Kooperatif Tipe Inkuiri pada tema Indahnya Keragaman di Negeriku subtema Keragaman Suku Bangsa dan Agama di Negeriku pembelajaran 1 di SD Negeri 060938 Medan Johor Tahun Pembelajaran 2020/2021 kelas IV adalah nilai terendah 65 dan nilai tertinggi hasil post test sebesar 100. Nilai rata-rata Post Test 82.96 berada dengan kategori baik sekali.

Di akhir pembelajaran, diberikan angket model pembelajaran yang akan di isi siswa sesuai langkah-langkah pembelajaran yang telah 
dilaksanakan oleh guru dan siswa dengan 14 pertanyaan. Diperoleh nilai rata rata angket siswa yaitu sebesar 53.56. Nilai angket siswa terendah sebesar 52 dan nilai angket siswa tertinggi sebesar 70. Dengan persentase tertinggi sebesar $33.3 \%$ dan persentase terendah sebesar $10 \%$.

Berdasarkan hasil normalitas dengan menggunakan taraf signifikan $5 \%$ atau 0.05 dengan rhitung < rtabel yaitu $0.178<0.05$. Dari hasil uji korelasi sebesar 0.621 artinya rhitung > rtabel yaitu $0.621>0.361$. Berdasarkan perhitungan hasil penelitian menunjukkan bahwa terdapat pengaruh model pembelajaran Kooperatif Tipe Inkuiri pada tema Indahnya Keragaman di Negeriku subtema Keragaman Suku Bangsa dan Agama di Negeriku di SD Negeri 060938 Medan Johor Tahun Pembelajaran 2020/2021 dengan $t_{\text {hitung }}>\mathrm{t}_{\text {tabel }}$ dimana $4.195>1.697$ pada taraf signifikan $\alpha=0.05$. Siswa dengan tema bendabenda di sekitar kita subtema benda zat tunggal dan campuran. Dengan demikian $\mathrm{H}_{\mathrm{a}}$ diterima dan $\mathrm{H}_{\mathrm{o}}$ ditolak.

\section{DAFTAR PUSTAKA}

Anggraini, B. N. W., Syachruddin AR, S. A., \& Ramdani, A. (2020). Pengaruh Penerapan Model Pembelajaran Inkuiri Terhadap Hasil Belajar Peserta Didik Tentang Sistem Gerak. Jurnal Pijar Mipa, 15(1), 32. 10.29303/jpm.v15i1.1056

Arikunto, S. (2018). Prosedur Penelitian Suatu Pendekatan Praktik. PT Rineka Cipta.

Artana, I., Dantes, P., \& Lasmawan, M. (2015). Pengaruh Model Pembelajaran Inkuiri Terbimbing Terhadap Hasil Belajar Ipa Ditinjau Dari Minat Belajar Siswa Kelas V Sd Negeri Di Gugus Vi Kecamatan Abang Kabupaten Karangasem Tahun Pelajaran 2014/2015. Jurnal Pendidikan Dasar Ganesha, 5(1), 124489.

Azwar, S. (2016). Metode Penelitian. Jakarta: Pustaka Pelajar.

Darmadi, H. (2014). Metode Penelitian Pendidikan dan Sosial. Bandung: Alfabeta.

Fathurrohman, M. (2015). Model-Model pembelajaran Inovatif (1st ed.). Ar-Ruzz Media.
Idrisah, I. (2014). Pengaruh Model Pembelajaran Inkuiri. 4(20), 196-207.

Istarani. (2017). 58 Model Pembelajaran Inovatif. Jakarta: Media Persada.

Istirani, \& Pulungan, I. (2018). Ensiklopedi Pendidikan. Media Persada.

Istirani, \& Pulungan, I. (2019). Ensiklopedia Pendidikan. Jakarta: Media Persada.

Kurniasih, I., \& Sani, B. (2016). Ragam Pengembangan Model Pembelajan. Yogya: Kata Pena.

Kurniawan, D. (2020). Pembelajaran Terpadu Tematik (Teori, Praktik, dan Penilaian). Bandung: Alfabeta.

Lubis, E. A. (2015). Strategi Belajar Mengajar. Bandung: Perdana Publishing.

Manullang, M., \& Pakpahan, M. (2014). Metodologi Penelitian. Bandung: Citapustaka Media.

Ngalimun. (2017). Strategi dan Model Pembelajaran. Bandung: Aswaja Pressindo.

Risa, U., Marungkil, P., dan A. R. (n.d.). Penerapan Metode Inkuiri Untuk Meningkatkan Hasil Belajar IPA Siswa Kelas IV SD Inpres Bajawali Kecamatan Lariang Kabupaten Mamuju Utara. 3(2354-614X), 157-166.

Rumiyati, N. (2015). Pengaruh Model Pembelajaran Inquiry Training.

Rusman. (2019). Pembelajaran Tematik Terpadu Teori, Praktik dan Penilaian. Jakarta: PT Rajagrafindo Persada.

Sagala, S. (2017). Konsep dan Makna Pembelajaran. Bandung: Alfabeta.

Shohimin, A. (2016). 68 Model Pembelajaran Inovatif dalam Kurikulum 2013. Bandung: Ar-Ruzz Media.

Sinaga, R., Mawati Zai, E., Anjelina, D., \& Janson Silaban, P. (2020). Penerapan Model Problem Based Learning Untuk Meningkatkan Hasil Belajar Tema Indahnya Kebersamaan Di Kelas IV. 6(2), 344-349.

Sinaga, R., Sitorus, \& Janson Silaban, P. (2021). Pengaruh Pendidikan Karakter Terhadap Hasil Belajar Siswa Kelas IV Di SD Negeri 114344 Blok III Tanjung Pasir. XII(1), 162-169. 
Jurnal PAJAR (Pendidikan dan Pengajaran)

Volume 5 Nomor 6 November | ISSN Cetak : 2580 - 8435| | ISSN Online : 2614 - 1337

DOI : http://dx.doi.org/10.33578/pjr.v5i6.8479

Slameto. (2019). Belajar dan Faktor-Faktor Yang

Mempengaruhi. Jakarta: PT Rineka Cipta.

Sugiyono. (2010). Metode Penelitian Kuantitatif Kualitatiffan $R \& D$. Alfabeta.

Susanto, A. (2016). Teori Belajar \& Pembelajaran di Sekolah Dasar. Kencana.

Yusuf, S., Suastra, I. W., \& Tokan, M. K. (2019). The effects of problem-based learning with character emphasis and naturalist intelligence on students' problem-solving skills and care. International Journal of Innovation, Creativity and Change, 5(3), 1-26. 